ピンチ・プラズマの圧縮過程に対する一つのモデル，N．

柴田兼敏, 松浦健哉, 川俣修一郎

(宇都宮大学 工学部)

( 1982 年 12 月 22 日受理 )

\title{
A Simple Model for an Implosion Dynamics of Pinch Plasma. IV.
}

\author{
Kanetoshi Shibata, Kenya Matsuura and \\ Shuichiro Kawamata
}

(Received December 22, 1982)

\begin{abstract}
Maximum pinch time of a plasma in a toroidal pinch device is obtained from magnetic probe measurement. This experimental result is in good agreement with the pinch time calculated from MHD shock wave model. It is verified that the model is very useful for an implosion of the pinch plasma.
\end{abstract}

§1. まえがき

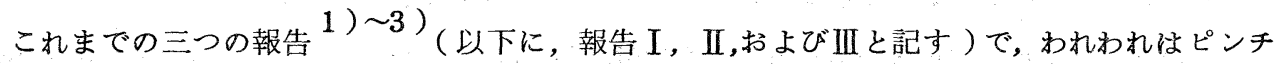
・プラズマの圧縮過程に対する一つのモデルを提案した。報告 Iでは，バイアス磁場のないとき の $\theta$ ピンチ・プラズマの压縮過程が, 報告II とIIIでは, バイアス磁場のあるときのそれが議論さ れた。これらにつづく本報告では，小型トロイダル・ピンチ装置におけるその実験結果を報告し てモデルによる解析結果との比較を行う。

モデルはプラズマの圧縮運動における電磁流体力学（MH D ）的な保存則にその基礎をおき， かつ，圧縮されてゆく有限幅の境界プラズマ層の前面が衝撃波面になっていることを基本として 構成されている（これらのことから，今後，MHD衝撃波モデルと呼ぶことにする）。これは境 界層内の個々の流体要素の圧縮運動を完全なMH D方程式の解として知るという正統的な理論の

Faculty of Engineering, Utsunomiya University, Utsunomiya 321 
柴田, 松浦, 川俣

立場に立脚したものでなく, 若干の仮定のもとで空間的に平均化された意味での巨視的な層の運 動を保存則のみに従って議論したものである（報告Ｉ参照）。つまり，あくまでもモデルの段階 のものである。それ故に，モデルがどの程度実験的に検証され得るかということが最も興味ある 重要な問題となる。このような観点から, 本報告はMH D衝撃波モデルの一つの実験的な検証を 試みたものである。

小型トロイダル・ピンチ装置に预ける圧縮過程の実験は正バイアス磁場の条件のもとでなされ， プラズマが最大に圧縮される時間 (最大圧縮時間) とガス初期圧, バイアス磁場および圧縮磁場 の立ち上がり速度との関係が実験的に観測された。用いられた装置のパラメーター, 実験条件, 観測手段等が第 2 節に, そして, 実験結果とその解析および考察がまとめて第 3 節に述べられて いる。モデルによる解析は報告したがって行われた。

\section{§2. 装置および実験方法}

装置とその実験方法についての概要を述べる。

実験は円型断面軸対称磁場配位をもつ小型トロイダルピンチ装置を用いて行われた。大半径 $25 \mathrm{~cm}$, 小半径 $5 \mathrm{~cm}$ のパイレックスガラス製ドーナツ型放電管がプラズマの電磁流体力学的平 衡を保障するために厚さ $3 \mathrm{~mm}$ の導体壁（銅製）で覆われている。その外側にはトロイダル磁場 発生用 $\theta$ ーコイルおよびプラズマ電流を流すための $z$ ーコイが巻かれている。主放電を開始す る以前に予備電離プラズマ中にバイアス磁場を印加するが，この磁場の発生には $\theta$-コイルが併 用されている。この装置の放電回路のパラメーターは第 1 表に示されている。

現在組み込まれている予備電離用 $\theta$ 型放電回路では, そのキャパシターのエネルギーが弱く予 備電離としては十分でない。そのためこれに加えてさらにクローバをしない主放電としての $\mathrm{z}$ 型 放電回路が用いられた。つまり $\mathrm{Z}$ バンクの放電開始後の最初の一周期が予備電離プラズマを生成 するために用いられた。したがって，本報告における実験では，われわれは主放電 $\mathrm{z}$ 回路，予備 電離用 $\theta$ 回路お吃びバイアス磁場回路が最初に放電され，これらの放電開始後 $76 \mu \mathrm{sec}$ で主 $\theta$ 放電を行った。予備電離用キャパシター， $z$ 用キャパシターおよび $\theta$ 用キャパシターの充電電圧 はそれぞれ $6 \mathrm{kV}, 10 \mathrm{kV}, 20 \mathrm{kV}$ である。そのとき, 主放電後のトロイダル磁場の值は最大 で約 $5 \mathrm{kG}$ ，プラズマ電流の值は $25 \mathrm{kA}$ である。バイアス磁場回路の充電電圧をそれぞれ $3 \mathrm{kV}$,

*）実際には，本報告で述べられる小型トロイダル・ピンチ装置の実験結果の一部がすでに得られて いて，これらの結果を如何に説明するかという模索からモデルが提案されたというのが経過である。 
ピンチ・プラズマの圧縮過程に対する一つのモデルN

第 1 表 放電回路の諸定数

\begin{tabular}{|c|c|c|c|c|c|}
\hline & & \multicolumn{2}{|c|}{ 主＼cjkstart放＼cjkstart電 } & \multirow{2}{*}{$\begin{array}{c}\text { 予備電離 加 熱 } \\
(\theta \text { 型 })\end{array}$} & \multirow{2}{*}{ バィアス } \\
\hline & & $\theta$ & $z$ & & \\
\hline エネルギー & $(k J)$ & 5.94 & 5.94 & 0.99 & 4.5 \\
\hline コンデンサー容量 & $(\mu \mathrm{F})$ & 13.2 & 13.2 & 2.2 & 90 \\
\hline 最大充電電圧 & $(\mathrm{kV})$ & 30 & 30 & 30 & 10 \\
\hline $1 / 4$ 放電周期 & $(\mu \mathbf{s})$ & 14 & 20 & 7 & 80 \\
\hline 最大トロイダル磁場 & $(k G)$ & \multicolumn{2}{|c|}{8} & - & 0.8 \\
\hline 最大プラズマ電流 & $(\mathrm{kA})$ & \multicolumn{2}{|c|}{70} & - & - \\
\hline
\end{tabular}

$5 \mathrm{kV}$ および $7 \mathrm{kV}$ に選んだ。そのときの磁場の值はそれぞれ 190 ガウス，400ガウス，560ガ ウスである。使用ガスはヘリウムである。実験は初期圧 $14 \sim 200 \mathrm{~m}$ Torr の範囲で行われた。

最大圧縮時間は放電管の断面の中心におかれた磁気探針により測定された。第 1 図がその観測波 形であり，それらは主 $\theta$ 放電開始前 $1 \mu \mathrm{sec}$ から開始後 $8 \mu \mathrm{sec}$ までの時間領域におけるトロイダ ル磁場の時間変化を示している。図において, 上の波 形はプラズマがないときの真空におけるそれであり， 下の波形はプラズマがあるときのものである。上の波 形は時刻 $\mathrm{t}_{\mathrm{a}}$ のところで正弦波状に立ち上がっており， この時刻 $\mathrm{t} a$ が主 $\theta$ 放電の開始時間である。 $\mathrm{t} a$ 以前 の時間的に殆ど一定な波高值は主放電直前のバイアス 磁場の值を示している。プラズマがあるときの波形の 時間変化は, プラズマの電気伝導度が極めて大きいと 仮定するとき，以下のように解釈することができる。 主 $\theta$ 放電開始後の極めて短かい最初の時間領域では, 時間変化する外部磁場 (これはほぼ真空磁場に等しい) の王力はプラズマの内部の圧力 (プラズマ圧力とバイ

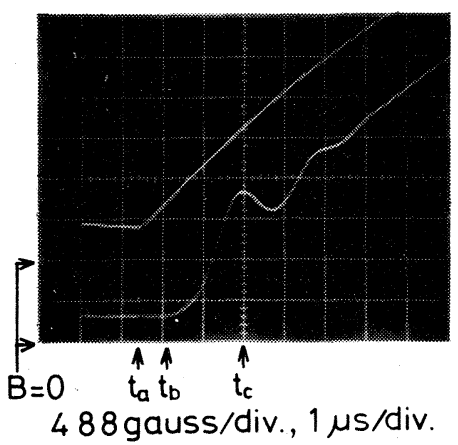

第1図トロイダル磁場波形 (初期压 $70 \mathrm{~m}$ Torr) 上：プラズマがない場合 下：プラズマがある場合 アス磁場圧力の和 )上り小さいために, プラズマは圧 
柴田, 松浦, 川俣

縮運動をしないであろう。つまり，圧縮運動は上記二つの圧力が丁度均衡する時刻 $\mathrm{t} 。$ より始ま る。上に述べたような電気伝導度に関する仮定のものとでは, $\mathrm{t}_{0}$ 以後もしばらくの間はプラズ マ柱断面の中心のトロイダル磁場の值は顕著な変化をしないと考兄られる。したがって,この時 間領域，つまり図における時刻 $\mathrm{t}_{\mathrm{b}}$ 程度までの間性観測波形は殆ど時間変化をせず，それ故に， われわれは時刻 $\mathrm{t}$ 。を波形から読みとることはできない。）プラズマがある程度圧縮された時刻, 即ち, 時刻 $\mathrm{t}_{\mathrm{b}}$ 以後, 波形からみられるように, プラズマの内部の磁場の值核激に増加してゆ き, 時刻 $\mathrm{t}_{\mathrm{c}}$ でその波高值は最初の最大值に達する。 $\mathrm{t}_{\mathrm{c}}$ 以後に発生している $2 \sim 3 \mu \mathrm{sec}$ の周 期の磁場の振動は， $\theta$ ピンチの実験において通常よく観測されている径方向振動である。以上の 考察から，時刻 $\mathrm{t} \mathrm{c}$ をもってプラズマの圧縮運動がほぼ終了したものとみなしてよい。こうして， プラズマの最大圧縮時間は $\mathrm{t}_{\mathrm{p}}=\mathrm{t}_{\mathrm{c}}-\mathrm{t}_{\mathrm{a}}$ としてトロイダル磁場の観測波形から実験的に決定さ れる。次節で，われわれはこのようにして得られる $\mathrm{t} \mathrm{p}$ に関係した種々の実験結果を示す。

最後に, 実験結果とモデルの計算結果との比較の際に必要とされる予備電離プラズマの密度と 温度および外部トロイダル磁場の立ち上がり速度の実験值について言及しておく。これらの值は モデルにおける計算值を求めるときの種々のパラメーター（報告IIIの S と B ) を決める際に必要 となるものである。われわれは予備電離プラズマの密度を知るのにまず複探針測定を試みた。こ の測定から，密度に関しては初期圧の10〜30\%の電離度である結果が得られた。電離度の実 験值は初期圧の值によって変化をしているが, 両者の值の間には必ずしも規則的な関係はなく， 初期圧の $14 \sim 200 \mathrm{~m}$ T or r の範囲でその電離度の值はほぼ上記の範囲にあったということで ある。これはこの種の装置で発生するプラズマに対する複探針測定の精度の限界であるとみなさ れる。しかしながら，過去のいろいろな予備電離放電の実験結果から電離度 $10 \sim 30 \%$ 妥当な 值である。そこで,われわれは解析に用いる予備電離プラズマの密度の值の一つとして, 上記範 囲の中間をとって初期圧の $20 \%$ 電離度を用いることにする。また，報告 I の第 4 節でも述べた ように, 不完全予備電離プラズマのピンチ実験では, 残っている中性原子は性縮過程でその殆ど が電離されて, ピンチ終了時にはプラズマは $100 \%$ 電離の状態に達していると考えてよい。こ のために, 解析は $100 \%$ 電離度の場合も行われる。一方, 温度に関しては, 複探針測定で注電

*) 主放電直前の予備電離プラズマの密度と温度およびバィアス磁場の值が実験的に知られているな らば, 時刻 $\mathrm{t} 。$ は両圧力の均衡する条件（または報告IIIの式（2.3））から理論的に求められ得る。 実際に, 本報告の実験におけるその值を求めると, 実験条件によって若干変化するが, およそ $\mathrm{t}$ 。 $=0.1 \sim 0.5 \mu \mathrm{sec}$ 程度となり，観測波形の $\mathrm{t}_{\mathrm{b}}$ よりは小さい。 
子温度の値が $10 \mathrm{eV}$ 以上というかなり高い結果を得た。この原因は明白でないが, 予備電離プラ ズマの電子温度としては余りにも高すぎるように思われる。そこで, 前に述べたように, 予備電 離の段階ですでに $z$ 一回路を放電していることから，ループ電圧とプラズマ電流を測定すること により予備電離プラズマの電気抵抗率を求め, この值から電子温度を導くことを試みた。この方 法ではプラズマ電流の最大になる時刻ではかなり正確に電子温度を求めることができる。われわ れはこのときの電子温度の値から主 $\theta$ 放電開始時刻における予備電離プラズマの電子温度を推定 した (文献 4 ) の 3.3 節参照 )。この温度の值は初期圧およびバィアス磁場によって若干変化す

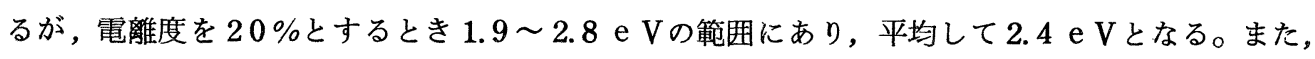
この電子温度に関しては, 次のような方法も試みられた。それは, 主一放電後の圧縮がまだ顕著で ない初期の時間領域における磁場の拡散係数を測定し, これよりプラズマの電気抵抗率を求めて 電子温度を算出する方法である。この方法による測定結果は $2 \sim 3 \mathrm{eV}$ 範囲にあり,ループ電 圧測定の場合とほぼ一致したものになっている。 の結果を予備電離プラズマの電子温度の值として罗当なものと結論し, そして, 電子温度とイオ ン温度は等しいものと仮定して, ${ }^{*}$ 解析に用いるプラズマ温度を $\mathrm{T}=5.6 \times 10^{4}{ }^{\circ} \mathrm{K}(4.8 \mathrm{eV})$ とした。次に，圧縮の際ピストンの役割を演ずる外部トロイダル磁場を報告III の式（III 2.1 )の ようにとるとき, 主 $\theta$ 放電開始時のその立ち上がり速度 $(\mathrm{dB} \mathrm{e} / \mathrm{d} \mathrm{t})_{\mathrm{t}=0}$ が解析に必要とな る。この值は磁気探針による真空磁場（またはプラズマのあるときの放電管壁におけるトロイダ ル磁場）の観測波形から, 放電開始後 $1 \mu \mathrm{sec}$ の時刻における波高值を用いて算出された。主放 電 $\theta$ 回路のキャパシターを $20 \mathrm{kV}$ に充電した典型的な場合におけるその值は $(\mathrm{dB} / / \mathrm{d} \mathrm{t}) \mathrm{t}=0$ $=5.45 \times 10^{8} \mathrm{gauss} / \mathrm{sec}$ である。

\section{§3. 実験結果および考察}

ここでは, 実験によるピンチ・プラズマの最大圧縮時間の測定結果を述べ, これらと MH D 衛 揧波モデルによる計算結果との比較, 検討を行う。数值解析には報告III ${ }^{3)}$ の計算式が用いられ る。

第2図（ａ）はバィアス磁場 190 ガウスを印加した場合の最大圧縮時間の初期圧依存性を示す。 同図 (b ) 拈よび ( c ) はバイアス磁場がそれぞれ 400，560ガウスの場合の結果である。×印が

*) この仮定は実験的には必ずしも自明のことではないが, 電磁流体力学に基ずくモデルの解析でこ のように考えるのは妥当であろう。 


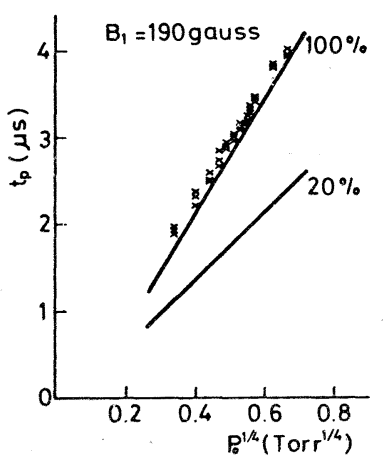

(a) : バイアス磁場 190 ガウスの場合

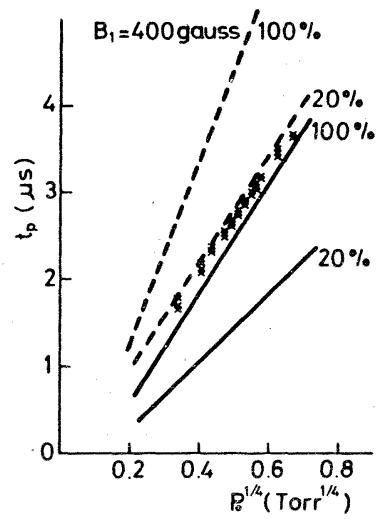

(b)：バイアス磁場 400 ガウスの場合

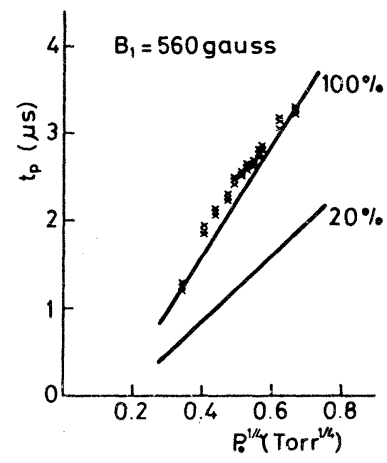

(c) : バイアス磁場 560 ガウスの場合

第 2 図 最大圧縮時間の初期圧依存性

前節で述べた方法で測定された実験值であり，実線はモデルによる計算值である。前節で述べたよ うに，計算值はプラズマの電離度が $20 \%$ と $100 \%$ 場合の 2 通りについて求められた。ここで, 典型的な実験条件のもとでのモデルに関係した二つのパラメーターS，Bの值を参考のために示し ておくと, 初期圧 $70 \mathrm{~m}$ Torr ，バイアス磁場 400 ガウスおよび主 $\theta$ 放電回路のキャパシター $20 \mathrm{kV}$ 充電の場合におけるそれらの值は，20\%電離で $\mathrm{S}=0.384$ および $\mathrm{B}=1.435$ であり， $100 \%$ 電離で $\mathrm{S}=0.574$ および $\mathrm{B}=0.642$ である。

これらの図から，まず第一に，実験から得られるプラズマの最大圧縮時間は計算值と同様にほぼ 初期圧の $1 / 4$ 乗に比例して長くなることがわかる。この比例関係は，実験的には，既に，S . Kiyama ${ }^{5}$ ) のバイアス磁場のない場合の直線 $\theta$ ピンチの実験でも報告されており，彼等は央験 結果の解析を反射イオンモデルで行っている。また, 計算値におけるこの比例関係は, 図の実線で 示されているMHD衝撃波モデルによるものの他に，これまでによく知られている雪かきモデルや 反射イオンモデルにおいても与えられることである。しかしながら，理論的にすっきりした形でこ れらのモデルにプラズマ圧力やバイアス磁場の効果を考慮することは必ずしも簡単でない。このよ うな観点から，われわれはこの一連の報告で電磁流体力学にその基礎をおく $\mathrm{MHD}$ 衝撃波モデルを 提案したものであり，したがって，本報告では原則としてこれらのモデルについては言及しない。 ただ, 雪かきモデルについては, 単なる参考として, 後に, 第 2 図 (b)の実験結果と関連させて 若干の考察を行う。

さて，第 2 図において，バイアス磁場のいずれの值の場合でも，実験值が $20 \%$ 電離よりむしろ 
ピンチ・プラズマの圧縮過程に対する一つのモデル，N.

$100 \%$ 電離の場合の計算值によく一致していることは非常に興味深い。もともと，モデルによる 計算値は, 主放電印加直後から最大に圧縮する時刻までの間, プラズマがその電離度の值のままの 状態にあることを前提として算出されたものである。しかしながら，通常のピンチの実験における と同様に, 本報告の実験においても最初不完全電離であったプラズマは, 圧縮過程の途中において 残っている中性原子が電離してゆき, 最も収縮した時にはほぼ完全電離に近い状態になっていると 考えてよい。そして, 主放電印加後の極めて早い時間にそれらの中性原子のほとんどが電離すると 仮定できるならば，実験值が $20 \%$ 電離より $100 \%$ 電離の計算值に一致することの方が罗当であろ う。また，この実験事実と上の考察に関連して，われわれは，バイアス磁場のないときのモデルの

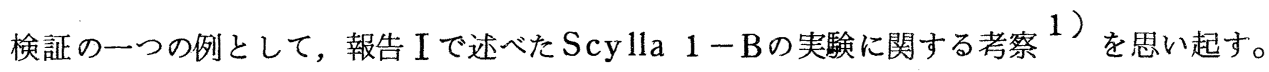
Scylla 1-Bの実験によるプラズマの密度は，まず，15\%電離の計算值に沿って時間変化し， この電離度の場合の最大圧縮時間を過ぎた付近からそれは急激に増加する。その後, プラズマの密 度は, ほぼ $100 \%$ 電離の計算曲線に沿って変化し, そして, プラズマはこの電離度の場合の最大 圧縮時間の計算値付近で実験的に最大圧縮に達していることが報告された。本報告における実験に おいても当然 Scylla 1-Bの実験に類する現象が起きていることが考えられて, 実験值が 100 \%電離の計算值によく一致することは十分に理解されることである。

われわれは, 参考のための一例として, 最大圧縮時間の雪かきモデルによる計算結果を第 2 図 （b）に示した。図の破線がそれである。また，この計算に関係したモデルの概要と若干の考察を 附録 $\mathrm{A}$ に述べておいた。図は，MHD衝撃波モデルの場合とは逆に，実験值が $20 \%$ 電離のときの 計算値に一致していることを示している。この傾向は他のバィアス磁場の值のときも同様である。 しかしながら，前に述べたように残っている中性原子の殆どが圧縮の過程で電離されることを考え るとき,この一致は理解しがたいように思われる。だからと言って, この事実だけから雪かきモデ ルが実験と一致しないと一般的に結論することは罗当ではない。しかし，われわれはプラズマが流 体的振る舞いの側面を十分にもっている低温, 高密度のプラズマのピンチ実験では, この一連の報 告で提案しかつ議論をしてきたMHD衝撃波モデルの方がより実際的でもっともなモデルのように 考える。附録Aのような形で求めた雪かきモデルによる最大圧縮時間に対する計算值は，パラメー ターS とBのすべての值の範囲で，MH D衝撃波モデルによるものより大きい值を与える傾向にあ ることをつけ加えておく。

次に, 第 3 図に最大红縮時間のバイアス磁場依存性を示す。○印と×印は初期压がそれぞれ 50 mTorr と $100 \mathrm{~m}$ Torr の実験值であり，実線はその圧力で $100 \%$ 電離を仮定したときのモデ 
柴田，松浦，川俣

ルによる計算值である。最大圧縮時間の実験值および 計算値はともにバイアス磁場か漒くなるにしたがって小さ くなることがわかる。そして, 実験值のバイアス磁場依存 性の傾向はほほ100\%電離の計算値のそれに一致してい る。このバイアス磁場依存性の実験事実は, 報告IIお よび而の解析結果を通じて, 次のような二つの理由か ら説明される。その一つは, バイアス磁場が強くなる とともに衝撃波面の速度は大きくなることである。し かし，最大圧縮時間は主放電開始時刻からプラズマが 最大に圧縮されるまでの時間で定義されているので, この理由だけからは実験事実を説明することは必ずし もできない。もう一つの理由はプラズマが圧縮を開始

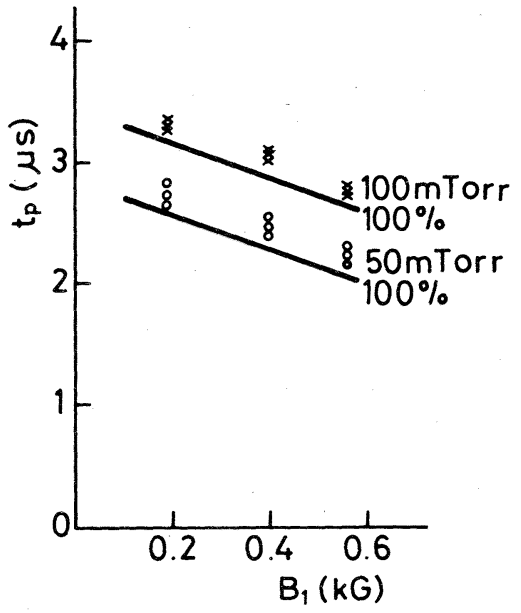

第 3 図 最大圧縮時間のバイアス磁場依存性 する時間，つまり報告IIまたはIIIで定義された初期時間のバイア ス磁場依存性にある。報告III の第 2節で詳細に述べたように，ピストンの役割を演ずる外部磁場の設定を式（III 2.1）のようにとる とき，初期時間の值はバイアス磁場の值が大きくなるにつれて小さくなってゆく。これがもう一つ の理由である。実験結果の解析において，外部磁場が式（III 2.1 ）のような形をとることの正当性 は，本報告第 1 図の磁場の観測波形から明らかである。外部磁場を報告川のようにとるとき（式 (II． 2.16)), 初期時間の值はバイアス磁場とともに増加してゆき，そして，その増加分は第一 の理由による衝撃波面の速度に起因する圧縮時間の減少分に打ち勝って, 結果として最大圧縮時間 はバイアス磁場とともに大きくなる。したがって，報告IIにおける解析では実験事実は説明できな くなる。以上の考察の観点から，われわれは初期時間を直接に測定することは困難であるが，最大 圧縮時間のバイアス磁場依存性の実験は報告吕における初期時間とバイアス磁場の関係の間接的な 証明と考えることもできる。

第 4 図に, 外部磁場の立ち上がり速度と最大圧縮時間の関係を示した。実験はバイアス磁場と初 期圧の值を固定したいくつかの場合がなされて計算值との比較がなされたが，それらの傾向はすべ ての場合について全く同じであるので，ここではバィアス磁場 400 ガウス，初期圧 $90 \mathrm{mTorr}$ の 典型的な場合の一例を挙げるにとどめる。図におけるメ印は実験值であり，実線はモデルによる計 算值である。同図より，外部磁場の時間的立ち上がり勾配が大きい程プラズマの圧縮は早く完了す ることが理解される。また, 初期圧依存性のときと同様に, 実験的に得られるプラズマの最大圧縮 
ピンチ・プラズマの圧縮過程に対する一つのモデル $\mathbf{N}$

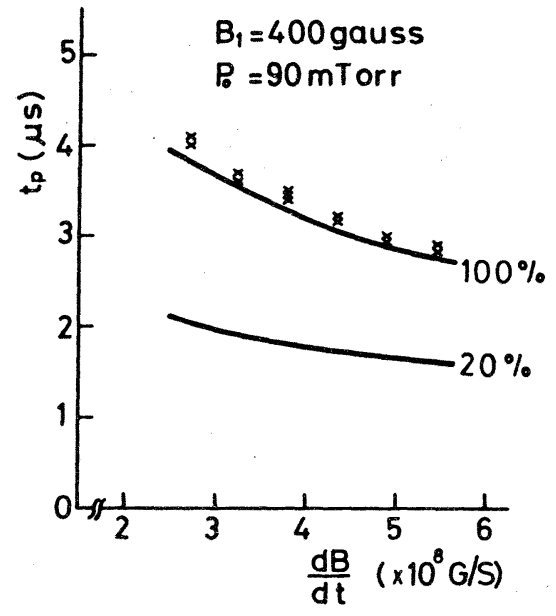

第 4 図

外部磁場の立ち上がり速度と最大圧縮時間の関係
時間は $100 \%$ 電離を仮定した計算曲線にほぼ一 致していることがわかる。 最後に, 以上の本報告でなされた実験結果と その解析に関連した三つの事柄について若干の 考察を述べておこう。まず第一に，実験はト口 イダル型の装置で行われたために, プラズマの 圧縮運動へのトロイダル効果についてである。 主 $\theta$ 放電後のプラズマ柱の流しカメラ写真測定 によると, 最大圧縮時にはプラズマはほぼ放電 管断面の中心に圧縮をしており,そして, 実験 条件にも関係するが, プラズマ柱がドーナツ形 状の外側に向かって運動をして壁に到達するの

は放電後約 $10 \mu \mathrm{sec}$ である。したがって, 放電開始後 $2 \sim 3 \mu \mathrm{sec}$ の間で生ずるプラズマの 圧 縮過程へのトロイダル効果は無視できると考えてよいだろう。このことから，解析においてわれわ れはプラズマの形状が直円筒であることを仮定した。第二の事柄はプラズマ電流 $\mathrm{I}$ p 圧縮運動へ の影響についてである。実験において主 $\theta$ 放電開始時にその值が零から立ち上がるような若干のプ ラズマ電流が流されており,この電流の圧縮運動への影響が考えられる。しかし，本報告の実験条 件の範囲内ではこの電流のつくるポロイダル磁場の大きさは主 $\theta$ 放電によるトロイダル磁場の約 $1 / 10$ 程度のものである。したがって, プラズマの圧縮現象は殆どトロイダル磁場によって支配 されていると考えてよい。第三の事柄は解析における予備電離プラズマの温度の值についてである。 その温度の值の決定は第 2 節に詳しく述べたが，厳密なことを言うならば，実験条件毎にそれに対 応した温度でもって解析が行われなければならない。それにも拘らず，モデルによる解析では，わ れわれはバイアス磁場や初期圧等の実験条件が変化してもプラズマ温度を一定とみなした。このこ とは次のような理由によるものである。われわれが行った実験条件の範囲内で電子温度の測定值は $1.9 \sim 2.8 \mathrm{e} \mathrm{V}$ と狭い範囲でだけ変化しており, その変化は測定の誤差の範囲にあって必ずしも規 則的ではなかったことにある。そして，もう一つの理由はモデルによる最大圧縮時間の計算值が予 備電離プラズマのプラズマ温度の考えられ得る値の範囲では殆ど変化をしないことである。このこ とを示すために, われわれは温度の值が $1.7 \sim 8.6 \mathrm{eV}\left(2 \times 10^{4}{ }^{\circ} \mathrm{K} \sim 10 \times 10^{4} \quad{ }^{\circ} \mathrm{K}\right)$ の範 囲における最大圧縮時間の温度依存性を第 5 困に示しておいた。かくして，プラズマ温度を一定と 
した解析結果と実験結果の比較に関する 本報告でなされた考察は罗当なものであ ると言える。

§4. あとがき

本報告で, われわれは小型トロイダ ル・ピンチ装置を用いてバイアス磁場 のある場合のプラズマの最大圧縮時間 の実験結果を述べ, 報告IIIのモデルに よる計算結果との比較を行った。本報 告で得られた結果は以下のようになる。

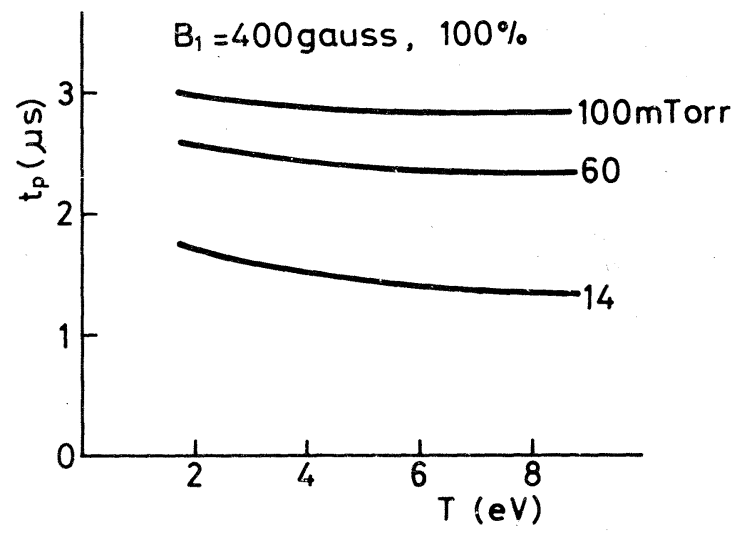

第 5 図最大圧縮時間のプラズマ温度依存性 (モデルによる計算結果) 第一に, プラズマの最大圧縮時間は初期圧の $1 / 4$ 乗に比例する関係にあること, 第二に, バィ ア大磁場が強い程この時間は短かいこと, 第三に, 外部磁場の立ち上がり速度が大きくなるにつ れて, 最大圧縮時間は短かくなることが実験的に確かめられた。第四に一これが本報告の最大 の結果であるがーMHD衝撃波モデルがこれらの実験結果を非常によく説明することである。 換言すれば，この一連の報告で提案され，かつ，議論された $\theta$ ピンチ・プラズマの圧縮過程に対 するモデルの一つの実験的な検証が与光られた。

ここで，実験結果について若干の見解を述べておく。本報告でなされた実験条件の範囲内では， 第一の実験結果はかなり正確にその比例関係が成立していることを示している。MH D衝撃波モ デルによれば，この関係は実験条件に対応したモデルの二つのパラメーターSおよびB（定義式

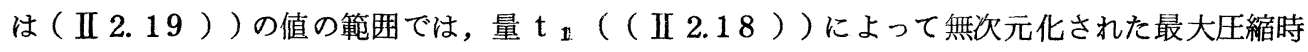
間 $\tau_{\mathrm{p}}=\mathrm{t}_{\mathrm{p}} / \mathrm{t}_{1}$ がほぼ同じ值をとることに起因している。即ち,このようなとき $\mathrm{t}_{\mathrm{p}} \propto \mathrm{t}_{1}$ と なり,したがって, $\mathrm{t}_{\mathrm{p}} \propto \rho_{1}^{1 / 4} \propto \mathrm{p}_{0}^{1 / 4}$ となるからである( $\rho_{1}$ は圧縮前のプラズマ,つまり 予備電離プラズマの質量密度である)。しかしながら， $\mathrm{S}$ 抒よび $\mathrm{B}$ の值のより広い範囲にわたっての 実験が行われるならば，この比例関係注必ずしも成立しない。このことは報告 IからIIIまでの ${ }^{\tau} \mathrm{p}$ のS および B 依存性の解析結果から明かである。ところが，このような広い範囲の実験条件 にわたっての実験は, パラメーターの值を変化させるための実験装置やピンチ・プラズマ生成に 関係した実験上の制限あるいはモデルに考虑されていない他の物理現象の検討を必要とするとい う解析上の難しさから，かなりの困難を伴うであろう。第二の結果は，モデルの立場から眺める 


$$
\text { ピンチ・プラズマの圧縮過程に対する一つのモデル } \mathrm{N}
$$

とき, 前節に詳しく述べたように, プラズマが圧縮を始める初期時間のバイアス依存性を強く反映 したものである。初期時間はプラズマ内部の圧力と外部压縮磁場の圧力が平衡することから得られ るものであり，実験的には直接測定することは困難な量であると考えられる。したがって，第二の 実験結果はこの依存性の間接的な証明になっていると考えてよいであろう。第三の結果はこの種の ピンチ・プラズマの圧縮過程の実験では至極当然のことである。

最後に, MHD衝撃波モデルの有効性がピンチ・プラズマの最大圧縮時間に対して実検的に検証 されたことは重ねて強調されるべきことである。このモデルは本報告の実験結果の解析でみられた ように，正バイアス磁場の場合の $\theta$ ピンチ・プラズマの压縮過程に対して非常に有用である。報告 IIIの外部磁場の表式（III 2.1 ）において，バィアス磁場 $\mathrm{B}_{1}$ を負の值にとれば，モデルは負バィア 不磁場の場合においても原則的に使用できる。しかし，この場合においても，正バイアス磁場の場 合におけるように実験事実をよく説明するか否かは現在の段階では明白でない。これは今後の検討 すべき興味ある問題である。

適切なアドバイスを頂いた宇都宮大学の本沢忠夫氏に謝意を表します。

参考文献
1) 松浦健哉，柴田兼敏 ； 核融合研究 46 (1981) 605 .
2) 松浦健哉，柴田兼敏 ； 核融合研究 46 (1981) 629 .
3) 松浦健哉，柴田兼敏 ； 核融合研究 48 (1982) 549 .
4) 柴田兼敏，松浦健战 ； 核融合研究 48 (1982) 173.

5) 木山学；電子技術総合研究所研究報告 第 787 号 (1978).

6) M. Rosenbluth, R. Garwin, and A. Rosenbluth ; Los Alamos Report-LA-1850 (1954).

7) L. A. Artsimovich : Controlled Thermonuclear Reactions, Oliver and Boyd. London 1964. 


\section{附 録 A}

雪かきモデル $\left.{ }^{6}\right)$ の概要とそれに関する若干の考察を述べておこう。よく知られているように, こ のモデルは，円柱状のプラズマにおいて，磁場ピストンによってかき集められてゆくプラズマで形成 される無限に薄い境界プラズマ層の中心軸への運動として定式化されている。その層の運動の.式は

$$
\frac{\mathrm{d}}{\mathrm{dt}}\left\{\pi \rho_{1}\left(\mathrm{r}_{0}^{2}-\mathrm{r}^{2}\right) \frac{\mathrm{dr}}{\mathrm{d} t}\right\}=-\frac{\mathrm{r}}{4} \mathrm{~B}_{\mathrm{e}}^{2}(\mathrm{t})+\frac{\mathrm{r}}{4} \mathrm{~B}_{\mathrm{i}}^{2}(\mathrm{t})+2 \pi \mathrm{r} p(\mathrm{t})
$$

で与えられる。 $\rho_{1}$ はプラズマの初期質量密度, $\mathrm{r}_{0}$ は は放電管の半径, $\mathrm{B} \mathrm{e}$ はピストンの役割を演ず る真空外部磁場, $\mathrm{B}_{\mathrm{i}}$ はプラズマの内部磁場 (バイアス磁場 ), $\mathrm{p}$ はプラズマの圧力である。通常, 雪かきモデルは右辺第 1 項の外部磁場による圧力だけを考慮するのが普通である。しかしながら，こ こでは，プラズマの圧縮を抑制する方向に働くバィアス磁場とプラズマの圧力の効果を含めることに する。圧縮運動の任意の各時刻において, バイアス磁場の磁束密度がプラズマ内部で保存されること およびL．A．Artsimovich 7) に従ってプラズマ圧力が断熱圧縮の性格をもつことを仮定する とき, ( A · 1 ) は容易に書き改められて, その無次元化した式は,

$$
\frac{d}{d \tau}\left\{\left(1-x^{2}\right) \frac{d x}{d \tau}\right\}=-x \tau^{2}-2 B S x \tau+B^{2} S^{2} \frac{1-x^{4}}{x^{3}}+\frac{2 S^{2}}{r} x-2 \gamma+1
$$

となる。ここで外部磁場は, 報告而と同様に，

$$
\mathrm{B}_{\mathrm{e}}(\mathrm{t})=\mathrm{B}_{1}+\left(\frac{\mathrm{dB}}{\mathrm{dt}}\right)_{\mathrm{t}=0} \mathrm{t}
$$

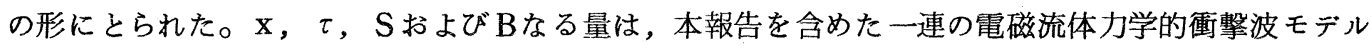
に関する報告におけると同じように，

$$
\begin{aligned}
& \mathrm{x}=\frac{\mathrm{r}}{\mathrm{r}_{0}}, \tau=\frac{\mathrm{t}}{\mathrm{t}_{1}}, \quad \mathrm{~S}=\frac{\mathrm{a}_{1} \mathrm{t}_{1}}{\mathrm{r}_{0}}, \quad \mathrm{~B}=\frac{\mathrm{b}_{1}}{\mathrm{a}_{1}} \\
& \mathrm{t}_{1}=\frac{\left(4 \pi \rho_{1} \mathrm{r}_{0}^{2}\right)^{1 / 4}}{\left(\frac{\mathrm{dB}}{\mathrm{dt}}\right)_{\mathrm{t}=0}^{1 / 2}}, \quad \mathrm{a}_{1}=\sqrt{\frac{r \mathrm{p}_{1}}{\rho_{1}}}, \quad \mathrm{~b}_{1}=\sqrt{\frac{\mathrm{B}_{1}^{2}}{4 \pi \rho_{1}}}
\end{aligned}
$$

で定義された。 $\mathrm{B}_{1}$ と $\mathrm{p}_{1}$ はそれぞれバイアス磁場とプラズマ圧力の初期値である。圧縮を始める初 期時間 $\tau_{0}$ は， $\mathbf{x}=1$ において（A．2 ）の右辺がゼロとなるときの $\tau$ の值で与えられ，それは 


$$
\text { ピンチ・プラズマの圧縮過程に対する一つのモデルN }
$$

$$
\tau_{0}=\left\{\sqrt{\frac{2}{r}+B^{2}}-B\right\} S
$$

となる。境界層の運動の軌跡 $\mathrm{x} （ \tau)$ は $\tau=\tau_{0}$ で $\mathrm{x}=1$ なる初期条件のもとで，（A，2）を数值 計算することで求められる。そして, 最大圧縮時間は $\mathrm{x}(\tau)=0$ となる時刻で定義される。雪かき モデルによる最大圧縮時間と初期圧の関係を示す第 2 図 (b) の破線は, このようにして得られたも のである。

バイアス磁場とプラズマ圧力の効果を上のような形で導入した雪かきモデルの定式化において，わ れわれは強調しておかねばならないことがある。外部磁場ピストンでかき集められてゆくプラズマ粒 子は, すべて, 無限に薄い境界首に集積されると考光られているが, それに反して, プラズマの圧力 とプラズマに凍りついて運動するバイアス磁場の磁束は運動の各時刻毎に压縮されてゆくプラズマ柱 の断面内に瞬時に平均化されなければならない。これら二つの事柄は，その平均化において粒子間の 衝突という物理的な機構を想定するとき，互いに相矛盾することになるだろう。雪かきモデルの基本 式をもとに，これらの矛盾が生じないょうに問題を定式化する “修正された雪かきモデル”を考方る ことも可能である。しかしながら，われわれはそのような修正された雪かきモデルを考えるよりも， むしろ, 問題に対する正攻法として, 電磁流体力学に忠実にその基礎をおく新しいモデルの提案を意 図した。つまり，本報告を含めての一連の報告の出発点は，この報告でなされた実験結果をどのよう に説明するかということとともに, この目的のためにどのようなモデルをつくったらよいかであった とも言える。勿論, 雪かきモデルはバイアス磁場とプラズマ圧力の圧縮運動への効果を無視する限り， 上記のような矛盾は生ずることなくプラズマ・ピンチに対して簡単でかつ物理的に明快なモデルであ る。 